\title{
企画展示
}

\section{一目瞭然！ 最新の射出成形}

高 原 忠 良 ${ }^{* 1}$ 撰 裕 喜*2 - 嶋村亜佑子*3

昨年好評をいただいた，企画展示「自動車関連技術の過 去 $\rightarrow 未$ 来」に引き続き, 本年は樹脂の成形加工法として広 く普及している「射出成形」にスポットを当てた．幅広い 層の方々に喜んでいただけるよう, 射出成形の歴史を示す ものから, 最新の成形機 - 金型 - 工法 - 材料の視点の内容 まで, 見て楽しい・役に立つ・学べる展示となるよう, 歴 史, 教育, 最新技術の 3 ゾーンに分け 23 点の展示品を紹 介した.

歴史ゾーンには，歴史的遺産となる射出成形機や金型， 教育ゾーンには, 射出成形の基礎を学べるデモ機や射出成 形時の挙動を観察できる可視化金型などを展示．また，最 新技術ゾーンには, 精密小型射出成形機から DSI 成形, 最新転写技術, 急加熱/急冷却成形技術など, 最新の成形 技術を多数展示した。アンケートでは「歴史の重さと, 成 形加工技術の進歩を感じた」との好評の声があり, 多数の 方に満足していただくことができた.

なお，展示には樹脂成形に関わるメーカー及び大学にご 協力いただき, 展示のための展示品の提供・梱包・運搬 ポスターの作成はすべて, 各企業による無償協力をいただ きました。

最後に，企画展示を遂行するに当たり，ご協力いただい た各社の皆様に感謝いたします。

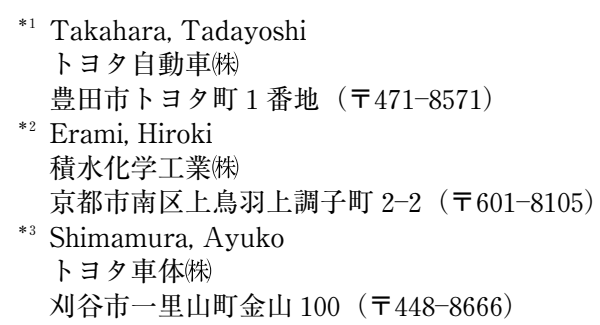

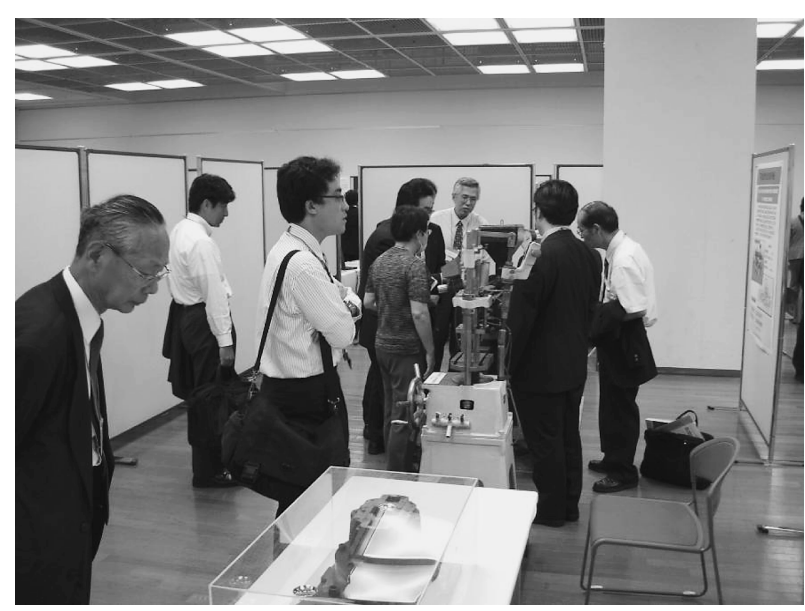

展示風景 1

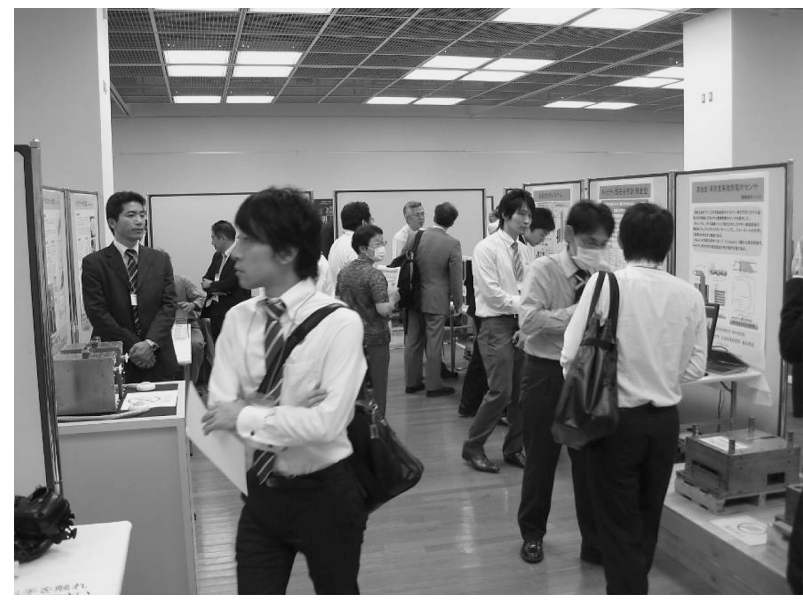

展示風景 2 